\title{
PARTISIPASI PEMUDA DALAM PEMBANGUNAN DESA (Studi Di Desa Kasimpa Jaya Kecamatan Tiworo Selatan Kabupaten Muna Barat)
}

\author{
La Pojo ${ }^{1}$, Misran Safar ${ }^{2}$, Abdul Halim Momo ${ }^{3}$ \\ Jurusan Pendidikan Pancasila dan Kewarganegaraan \\ Fakultas Keguruan dan Ilmu Pendidikan \\ Universitas Halu Oleo \\ Email:1apojo@gmail.com ${ }^{1}$, misransafar18@gmail.com ${ }^{2}$, \\ abdulhalimmomo@gmail.com ${ }^{3}$
}

\begin{abstract}
Abstrak: Tujuan penelitian ini adalah (1) untuk mengetahui bentuk-bentuk partisipasi pemuda dalam pembangunan Desa Kasimpa Jaya Kecamatan Tiworo Selatan Kabupaten Muna Barat? (2) untuk mengetahui Faktor-faktor apa yang mepengaruhi partisipasi pemuda dalam pembangunan Desa Kasimpa Jaya Kecamatan Tiworo Selatan Kabupaten Muna Barat. Penelitian dilakukan di Desa Kasimpa Jaya Kecamatan Tiworo Selatan Kabupaten Muna Barat. Penelitian ini bersifat kualitatif yaitu menggambarkan bentukbentuk dan faktor-faktor yang mempengaruhi partisipasi pemuda dalam pembangunan Desa Kasimpa Jaya Kecamatan Tiworo Selatan Kabupaten Muna Barat. Responden dalam penelitian ini adalah pemuda berjumlah 16 orang. Sedangkan Informan dalam penelitian ini berjumlah 3 orang yang terdiri dari; 1 orang Kepala Desa, 1 orang Tokoh Masyarakat dan 1 orang Ketua Badan Permusyawaratan Desa (BPD) Kasimpa Jaya. Hasil penelitian menunjukan bahwa bentuk-bentuk partisipasi pemuda dalam pembangunan desa yaitu a. Partisipasi dalam pembangunan pengerasan jalan usaha tani, partisipasi dalam pembangunan masjid, dan partisipasi dalam kegiatan pemugaran masjid. Faktor-faktor yang mempengaruhi partisipasi pemuda dalam pembangunan desa adalah faktor kemauan, faktor kemampuan, faktor kesempatan. Kesimpulan penelitian ini yaitu bentuk partisipasi pemuda dalam pembangunan pengerasan jalan usaha tani, kegiatan pembangunan masjid dan kegiatan pemugaran masjid di Desa Kasimpa Jaya Kecamatan Tiworo Selatan Kabupaten Muna Barat baik bentuk pikiran, tenaga ataupun uang/material dapat dilihat pada tahap pelaksanaan kegiatan pembangunan. Pada tahap pelaksanaan partisipasi pemuda sudah cukup baik. Akan tetapi pemuda dalam kegiatan pembangunan baik bentuk pikiran, tenaga ataupun uang/material pada tahap perencanaan dan evaluasi masih kurang berpartisipasi. Faktor-faktor yang mempengaruhi partisipasi pemuda dalam pembangunan di Desa Kasimpa Jaya Kecamatan Tiworo Selatan Kabupaten Muna Barat yaitu faktor kemauan, kemampuan dan kesempatan. Dengan demikian faktor yang dominan yang mempengaruhi partisipasi pemuda adalah faktor kesempatan.
\end{abstract}

\section{Kata Kunci: Partisipasi Pemuda, Pembangunan Desa}

\section{PENDAHULUAN}

Bangsa Indonesia selalu menekankan pentingnya asas pemerintahan dalam langkah-langkah pembangunan, namun dalam realisasinya masih tersendat-sendat. Keadaan seperti ini menuntut adanya keterampilan untuk mengembangkan sumber daya manusia yang ada di desa, dengan demikian akan terbentuk lapangan kerja. Pembangunan sumber daya alam setempat dapat juga dilakukan dengan member nilai tambah pada sesuatu yang tadinya tidak berharga. Hal ini hanya bias dilakukan jika, pengetahuan, keterampilan dan kepekaan memadai atau dengan kata lain pengembangan sumber daya alam membutuhkan perlunya pengembangan sumber daya manusia. Kualitas sumber daya sangat ditentukan oleh sikap mental 
manusia. Jadi jelasnya bahwa kualitas sumber daya tidak hanya di tentukan oleh keahlian seseorang saja.

\section{Konsep Partisipasi}

Istilah partisipasi sekarang ini menjadi kunci dalam setiap program pengembangan masyarakat dan seolah menjadi label baru yang harus melekat pada setiap rumusan kebijakan dan proposal proyek. Dalam perkembangannya sering kali diucapakan dan ditulis berulang-ulang tetapi kurang dipratekkan, sehingga cenderung kehilangan makna. Partisipasi sepadan dengan arti peran serta, ikut serta, keterlibatan atau proses belajar bersama saling memahami, menganalisis, merencanakan dan melakukan tindakan oleh sejumlah anggota masyarakat.

Partisipasi dalam kamus besar bahasa Indonesia yaitu tindakan ikut mengambil bagian, keikutsertaan atau ikut serta. Partisipasi berarti peran serta seseorang atau kelompok masyarakat dalam proses pembangunan baik dalam bentuk pernyataan maupun dalam bentuk kegiatan dengan memberi masukan pikiran, tenaga, waktu, modal dan atau materi, serta ikut memanfaatkan dan menikmati hasil-hasil pembangunan (I Nyoman Sumaryadi, 2010: 46).

\section{Konsep Partisipasi Pemuda}

Partisipasi pemuda merupakan salah satu keniscayaan yang perlu untuk dilaksanakan. Istilah partisipasi ini biasanya merupakan istilah yang digunakan untuk mendeskripsikan adanya keterlibatan segenap stakeholder terhadap aktivitas pembangunan. Dalam konteks tertentu istilah ini dikaitkan dengan aktivitas pemuda yang mandiri, mobilitas sosial, pembagian yang merata terhadap hasilhasil pembangunan.

Menurut Barry (2006: 323) mengemukakan bahwa partisipasi pada dasarnya merupakan hal ikut ambil bagian dalam suatu kegiatan, atau keikutsertaan dalam suatu kegiatan. Pandangan tersebut menunjukkan bahwa partisipasi sebagai kesediaan untuk membantu berhasilnya setiap program pembangunan sesuai dengan kemampuan setiap orang tanpa berarti mengorbankan diri sendiri. Mubyanto (2001: 77) mengemukakan bahwa secara luas partisipasi berarti sebagai kesediaan untuk membantu berhasilnya setiap program pembangunan sesuai dengan kemampuan setiap orang tanpa berarti mengorbankan diri sendiri. Sedangkan Slamet (2006:3) memaknai partisipasi sebagai keterlibatan aktif dan bermakna dalam proses pembentukan keputusan, pelaksanaan programprogram secara sukarela, dan penerimaan manfaat dari hasil-hasil program yang telah dilaksanakan.

\section{Bentuk - Bentuk Partisipasi Pemuda}

Menurut Effendi dalam Siti Irene (2011: 58), partisipasi dapat dibagi menjadi dua yaitu partisipasi vertikal dan partisipasi horizontal. Partisipasi vertikal terjadi dalam bentuk kondisi tertentu masyarakat terlibat atau mengambil bagian dalam suatu program pihak lainnya, dalam hubungan dimana masyarakat pada sebagai status bawahan, pengikut atau klien. Adapun partisipasi horizontal merupakan dimana setiap anggota atau kelompok masyarakat berpartisipasi horizontal satu dengan yang lainnya.

Sedangkan Mubyanto (2001: 46) membedakan bentuk partisipasi kedalam bentuk, tenaga, barang atau material, uang, ide/gagasan dan tanggung jawab. Keith 
Davis dalam Ibrahim Surotinojo (2006: 6) mengklasifikasikan partisipasi ke dalam 4 bentuk yaitu:

1. Pertisipasi uang adalah bentuk partisipasi untuk memperlancar usaha-usaha bagi pencapaian kebutuhan masyarakat yang memerlukan bantuan.

2. Partisipasi harta benda adalah partisipasi dalam bentuk menyumbang harta benda, biasanya alat-alat atau perkakas.

3. Partisipasi tenaga adalah partisipasi yang diberikan untuk pelaksanaan usahausaha yang dapat menunjang keberhasilan suatu program.

4. Partisipasi ketrampilan adalah memberikan dorongan melalui keterampilan yang dimiliki kepada anggota masyarakat lain yang membutuhkannya

Terkait dengan partisipasi pemuda maka partisipasi dapat diartikan sebagai suatu bentuk keterlibatan aktif dan bermakna yang dilakukan pemuda dalam proses kegiatan yang dilakukan secara sukarela guna mencapai tujuan yang telah ditetapkan. Irfani, (2004:1-2) mengemukakan bahwa terdapat 4 substansi pokok dalam pengertian partisipasi pemuda yang meliputi: (a) partisipasi dalam proses pengambilan keputusan; (b) partisipasi dalam implementasi kegiatan; (c) partisipasi dalam pemantauan dan evaluasi hasil-hasil program; (d) partisipasi dalam penerimaan manfaat/keuntungan yang diperolehdari program.

\section{Faktor-Faktor yang Mempengaruhi Partisipasi Pemuda.}

Ada beberapa faktor yang dapat mendukung dan menghambat partisipasi masyarakat dalam suatu program, Timbulnya partisipasi merupakan ekspresi perilaku manusia untuk melakukan suatu tindakan, dimana perwujudan dari perilaku tersebut didorong oleh adanya tiga faktor utama yang mendukung, yaitu (1) kemauan; (2) kemampuan; dan (3) kesempatan bagi masyarakat untuk berpartisipasi, Dorodjatin (Slamet, 2003:18). Ketergantungan masyarakat terhadap pemerintah dalam pelaksanaan kegiatan pembangunan merupakan hambatan dalam mewujudkan partisipasi atau keterlibatan masyarakat secara aktif, karena rasa ketergantungan ini masyarakat tidak memiliki inisiatif untuk melaksanakan pembangunan atau prakarsa mereka sendiri.

Menurut Kartono (1992: 31). Kemampuan adalah segala daya, kesanggupan/ keterampilan teknis maupun sosial, yang dianggap kemampuan anggota biasa sedangkan Kemauan merupakan motor penggerak untuk berpartisipasi. Seseorang harus mempunyai suatu kemampuan/keterampilan untuk dapat mempertahankan hidupnya, apabila seseorang sudah mempunyai kemampuan dan keterampilan dan tidak ada kemauan maka segala sesuatunya tidak akan terlaksana maka antara kemapuan atau keterampilan dengan keamauan harus seimbang supaya segala sesuatunya akan terlaksana. Begitu juga dengan pembangunan apabila seseorang yang mempunyai potensi untuk membangun desanya tetapi tidak mempunyai kemauan maka pembangunan tidak akan terlaksana.

\section{Konsep Pemuda}

Secara umum terdapat pergeseran mengenai konsep pemuda. Pada dua dekade yang lalu, terminology pemuda selalu memiliki makna ideologis. Pemuda, bukanlah sebuah gugus gagasan yang hanya dibatasi oleh persoalan umur semata. Pemuda, sebagai sebuah konsep, memiliki dimensi politis. Bennedict Anclerson, menyebut bahwa definisi "pemuda" selalu dikaitkan dengan dimensi politik. Sejak 
revolusi kemerdekaan, pemuda adalah kelompok umur tertentu (15-40 tahun) yang menghabiskan sebagian besar semua waktu longgar mereka dalam kegiatan yang sifatnya politis (Sudibyo, 2013:17).

Pemuda adalah individu yang bila dilihat secara fisik sedang mengalami perkembangan dan secara psikis sedang mengalami perkembangan emosional, sehingga pemuda merupakan sumber daya pembangunan baik saat ini maupun masa datang. Mulyana (2011 : 1) mengemukakan bahwa pemuda lebih dilihat pada jiwa yang dimiliki seseorang. Jika orang tersebut memiliki jika yang suka memberontak, penuh inisiatif, kreatif, anti kemapanan, serta ada tujuan membangun kepribadian, maka orang tersebut dapat dikatakan sebagai pemuda. Acuan yang kedua inilah yang ada pada masa lalu digunakan, sehingga pada saat itu terlihat bahwa organisasi pemuda itu lebih banyak dikendalikan oleh orangorang yang secara usia sudah tidak muda lagi, tetapi mereka memiliki jiwa pemuda. Oleh sebab itu kelemahan dari pemikiran yang kedua itu organisasi kepemudaan yang seharusnya digunakan sebagai wadah untuk berkreasi dan mematangkan para pemuda dijadikan kendaraan politik, ekonomi, dan sosial untuk kepentingan perorangan dan kelompok.

\section{Konsep Pembangunan Desa}

Pembangunan merupakan suatu kegiatan yang rasional yang dilakukan seluruh lapisan dan segenap golongan masyarakat untuk mencapai kehidupan yang lebih baik dari keadaan sebelumnya, dimana pembangunan tersebut harus direncanakan secara matang, cermat dan terarah agar pembangunan tersebut dapat berhasil dan berdaya guna bagi masyarakat.

Menurut Rahardjo (1999 : 94), mengemukakan bahwa pembangunan di Indonesia memiliki arti "pembangunan nasional yang ditunjukan pada usaha peningkatan taraf hidup masyarakat pedesaan, membutuhkan partisipasi aktif setiap anggota masyarakat terhadap pengembangan dan memciptakan hubungan yang selaras antara masyarakat dan lingkungannya". Selanjutnya, Ndaraha (1990: 92) mengemukakan dimensi dari pembangunan desa yaitu: "Sebagai proses, metode, program dan gerakan sosial. Sebagai proses, dalam hubungan ini menentukan nasibnya sendiri dan menempu berbagai upaya bersama untuk mencapainya. Sebagai metode, pembangunan masyarakat bekerja pada dua cara yaitu: (1) partisipasi masyarakat; (2) pengorganisasian masyarakat sebagai program, pembangunan masyarakat merupakan bagian integral pembangunan nasional yang titik beratnya pada pencapaian tujuan organisasi. Sebagai gerakan, pembangunan desa merupakan upaya untuk mewujudkan suatu ideologi (bagi bangsa Indonesia pancasila) sebagai gambaran sistematis suatu cita-cita yang ingin dicapai oleh suatu bangsa".

Kondisi Pemuda di Desa Kasimpa Jaya Kecamatan Tiworo Selatan Kabupaten Muna Barat sikap mental dalam pembangunan dapat digolongkan statis dan pasif. Partisipasi pemuda dalam kegiatan-kegiatan non fisik yang ada didesa masih dirasakan kurang. Misalnya kurang partisipasi dalam musyawarah dalam pembangunan fisik dan kurangnya partisipasi dalam kegiatan-kegiatan yang berbasis kepemudaan. Pemuda mempunyai kesempatan yang lebih besar untuk ikut serta dalam berpartisipasi dalam pembangunan didesa. Sebagai generasi bangsa yang mampu memberikan ide kreaktif dan inovatif untuk dapat memajukan pembangunan di desa dalam bentuk fisik atau non fisik. Tetapi faktanya partisipasi 
pemuda relatif masih dapat terbatas dalam pelaksanaan dari pembangunan. Berdasarkan hasil Observasi awal dalam penelitian ini bahwa partisipasi pemuda di Desa Kasimpa Jaya Kecamatan Tiworo Selatan Kabupaten Muna Barat. Kegiatan pembangunan desa seharusnya bukan hanya beban dan tanggung jawab pemerintah semata, akan tetapi menjadi tangung jawab seluruh masyarakat, terutama para pemuda. Karena ini partisipasi pemuda agar dapat menentukan arah pembangunan menuju arah kemajuan yang baik, maka penulis tertarik mengangkat satu penelitian denganj udul "Partisipasi Pemuda dalam Pembangunan Desa" di Desa Kasimpa Jaya Kecamatan Tiworo selatan Kabupaten Muna Barat.

\section{METODE PENELITIAN}

\section{Lokasi Penelitian}

Penelitian ini dilakukan di Desa Kasimpa Jaya Kecamatan Tiworo Selatan Kabupaten Muna Barat, dengan pertimbangan bahwa partisipasi pemuda di Desa Kasimpa Jaya dalam kegiatan pembangunan fisik belum sepenuhnya menyentuh masyarakat atau belum sesuai dengan keinginan masyarakat.

\section{Jenis Penelitian}

Jenis penelitian ini adalah jenis penelitian deskriptif kualitatif yaitu menggambarkan bentuk-bentuk dan faktor-faktor yang mempengaruhi partisipasi pemuda dalam pembangunan Desa Kasimpa Jaya Kecamatan Tiworo Selatan Kabupaten Muna Barat.

\section{Responden Penelitian dan Informan Penelitian}

Responden dalam penelitian ini adalah pemuda di Desa Kasimpa Jaya KecamatanTiworo Selatan Kabupaten Muna Barat dengan jumlah 16 orang. Sedangkan yang menjadi informan dalam penelitian ini berjumlah 3 orang yang terdiridari; 1 Kepala Desa, 1 orang Tokoh Masyarakat, dan 1 orang Ketua Badan Permusyawaratan Desa (BPD) Kasimpa Jaya Kecamatan Tiworo Selatan Kabupaten Muna Barat.

\section{Teknik Pengumpulan Data} berikut:

Dalam melakukan pengumpulan data peneliti mengunakan metode sebagai

1. Penelitian kepustakaan (library research), yaitu dengan mempelajari dan membaca berbagai literatur yang relevan dengan permasalahan dalam penelitian ini.

2. Penelitian lapangan (field research), yaitu pengumpulan data secara langsung dengan menggunakan metode: Observasi, wawancara (interview), dan dokumentasi

\section{Teknik Analisis Data}

Teknik analisis data yang digunakan dalam penelitian ini adalah deskriptif kualitatif, yaitu dengan tujuan menggambarkan, memaparkan dan menjawab permasalahan.

\section{HASIL DAN PEMBAHASAN.}

\section{Bentuk-Bentuk Partisipasi Pemuda Dalam Pembangunan Fisik Di Desa} Kasimpa Jaya.

Dalam pelaksanaan pembangunan di Desa Kasimpa Jaya, partisipasi pemuda sangat dibutuhkan guna mencapai tujuannya yaitu mencerdaskan kehidupan bangsa dan kesejahteraan kehidupan masyarakat. Namun kenyataanya 
pemuda yang berpartisipasi tidak terlepas dari berbagai pengaruh sehingga berlangsungnya partisipasi pemuda dapat terganggu. Partisipasi pemuda dalam pembangunan Desa Kasimpa Jaya pada tahun 2016-2017 dapat dilaksanakan menjadi 3 bentuk kegiatan, yaitu: (1) pengerasan jalan usaha tani. (2) pembangunan masjid, (3) pemugaran masjid.

Adapun bentuk-bentuk partisipasi pemuda dalam pembangunan desa kasimpa jaya adalah sebagai berikut:

a. Bentuk Pikiran

Gagasan atau ide cermerlang dapat menunjukan keberhasilan suatu rencana yang telah ditetapkan dan yang akan dilaksanakan. Oleh karena itu, sumbangan pemikiran berupa saran atau ide-ide yang sangat diharapkan dapat membantu upaya pencapaian dan perbaikan program-program pembangunan yang akan dilaksanakan supaya mencapai hasil yang maksimal. Partisipasi pemuda dalam bentuk pikiran biasanya disampaikan dalam musyawarah atau penyampaian program-program pembangunan desa.

Dari hasil penelitian yang dilakukan penulis, partisipasi pemuda dalam bentuk sumbangan pemikrin masih sangat kurang atau masih ada sebagian pemuda yang tidak ikut berpartisipasi. Adapun faktor-faktor yang menyebabkah hal tersebut adalah masih rendahnya tingkat pendidikan pemuda yang menetap dilingkungan desa saat ini, sehingga pemuda kurang mempunyai kemampuan ide kreatif yang dapat menunjang pembanguan dalam Desa Kasaimpa Jaya.

b. Bentuk Tenaga

Tingkat partisipasi pemuda yang paling sederhana dan lazim diberikan oleh anggota pemuda dalam membantu mensukseskan pelaksanaan suatu program pembangunan adalah berupa tenaga atau disebut dengan gotong royong. Gotong royong merupakan pengerahan tenaga kerja tanpa bayaran untuk suatu proyek yang bermanfaat untuk umumatau yang berguna untuk kesehjateraan masyarakat.

c. Bentuk Material atau Uang

Partisipasi pemuda dalam pembangunan fisik di Desa Kasimpa Jaya adalah memberikan sumbangan dalam bentuk material atau uang. Namun tidak dipaksakan berapa nominalnya yang harus di sumbangkan. Akan tetapi berdasarkan kerelaan pemuda itu sendiri demi untuk menunjang kegiatan pembangunan jalan usaha tani di Desa Kasimpa Jaya dengan baik dan lancar. Pemuda berpartisipasi dalam bentuk pikiran pada kegiatan pembangunan jalan usaha tani dilakukan pada tahap perencanaan, pelaksanaan, dan evaluasi kegiatan pembangunan.

Pemuda berpartisipasi dalam kegiatan pembangunan jalan usaha tani dengan bentuk material atau uang sebanyak pada tahap pelaksanaan. Pemuda menyumbangkan uang/material tanpa paksaan orang lain kerna masyarakat menyadari bahwa banyak sebagian pemuda belum mepunyai pekerjaan yang jelas atau berpenghasilan tetap. Pemuda yang berpartisipasi menyediakan seperti minuman, rokok bagi pemuda yang merokok serta makan sarapan seperti snack. 


\section{Faktor-Faktor yang Mempengaruhi Partisipasi Pemuda dalam Pembangunan Desa Kasimpa Jaya.}

Sebagaimana diketahui bahwa pembangunan tidak hanya merupakan usaha pemerintah semata atau masyarakat saja, akan tetapi partisipasi pemuda juga sangat diharapkan dalam kegiatan pembangunan desa agar dapat memberikan kemakmuran dan kesejahteraan bagi seluruh lapisan masyarakat. Keberhasilan pembangunan Desa Kasimpa Jaya merupakan cermin dari keberhasilan pembangunan nasional, karena itu titik berat pembangunan nasional diletakkan pada pembangunan Desa.

Apabila pembangunan tersebut dilaksanakan diwilayah Pedesaan, maka sudah jelas bahwa partisipasi masyarakat dan juga peran pemuda Pedesaanlah yang menjadi kunci keberhasilannya. Namun demikian peran serta pemua dalam proses pembangunan tentunya banyak faktor yang mempengaruhi tingkat keterlibatannya dalam pembangunan, menurut hemat penulis faktor yang mempengaruhi partisipasi pemuda dalam kegiatan pembangunan di Desa Kasimpa Jaya adalah faktor kemauan, kemampuan, dan kesempatan bagi pemuda untuk berpartisipasi dalam kegiatan pembangunan tersebut.

1. Faktor Kemauan

Keikutsertaan dalam suatu kegiatan pembangunan bukan timbul begitu saja akan tetapi karena adanya yang mendorong untuk partisipasi. Salah satu diantaranya adalah factor kesadaran pemuda itu sendiri. Apabila pemuda sudah sadar mengenai arti itu, maka jelas mereka juga akan lebih banyak melibatkan diri didalamnya. Hal ini dimaksudkan agar apa yang menjadi cita-cita pembangunan dapat tercapai yakni memberikan hidup sejahtera kepada semua warga masyarakat, demikian pula halnya dengan warga masyarakat Desa Kasimpa Jaya yang merupakan lokasi penelitian ini.

Dengan demikian factor kemauan yang mempengaruhi partisipasi pemuda dalam kegiatan pembangunan Desa Kasimpa Jaya dilakukan pada tahap perencanaan, pelaksanaan dan evaluasi. Terlihat bahwa factor kemauan yang mempengaruhi partisipasi pemuda dalam kegiatan pembangunan di Desa Kasimpa Jaya yaitu partisipasi pada tahap perencanaan dan evaluasi kegiatan pembangunan.

2. Faktor Kemampuan

Salah satu faktor yang mempengaruhi partisipasi pemuda dalam pembangunan Desa Kasimpa Jaya adalah karena factor kemampuan. Jika dihubungkan dengan tingkat kemampuan partisipasi pemuda dalam pembangunan memiliki tingkat kemampuan yang tinggi biasanya mempunyai perhatian yang besar terhadap kegiatan-kegiatan pembangunan yang dilakukan, baik pembangunan yang dilakukan pemerintah maupun yang merupakan swadaya masyarakat. Kenyataan ini memberikan gambaran bahwa betapa besar pengaruh kemampuan terhadap partispasi pemuda dalam pembangunan desa.

Dengan demikian factor kemmpuan yang mempengaruhi partisipasi pemuda dalam kegiatan pembangunan Desa Kasimpa Jaya dilakukan pada tahap perencanaan, pelaksanaan dan evaluasi.

Menurut Kartono (1992) bahwa kemampuan adalah segala daya, kesanggupan/keterampilan teknis maupun sosial, yang dianggap kemampuan anggota biasa. Sedangkan kemampuan merupakan motor penggerak untuk berpartisipasi. Seseorang harus mempunyai suatu kemampuan/keterampilan 
untuk mempertahankan hidupnya, karena apabila seseorang sudah mempunyai kemampuan atau keterampilan dan tidak ada kemauan maka segala sesuatunya tidak akan terlaksana. Maka antara kemampuan atau keterampilan dengan kemauan harus seimbang supaya segala sesuatunya akan terlaksana. Begitu juga dengan pembangunan apabila seseorang yang mempunyai potensi untuk membangun desanya tetapi tidak mempunyai kemauan maka pembangunan tidak akan terlaksana.

3. Faktor Kesempatan

Dengan demikian faktor kesempatan yang mempengaruhi partisipasi pemuda dalam kegiatan pembangunan Desa Kasimpa Jaya dilakukan pada tahap perencanaan, pelaksanaan dan evaluasi.

Faktorkemauan yang mempengaruhi partisipasi pemuda dalam kegiatan pembangunan di DesaKasimpa Jaya yaitu partisipasi pada tahap perencanaan dan evaluasi kegiatan pembangunan. Dorodjatin (Slamet, 2003) mengatakan bahwa faktor yang dapat mendukung dan menghambat partisipasi masyarakat dalam suatu program, Timbulnya partisipasi merupakan ekspresi perilaku manusia untuk melakukan suatu tindakan, dimana perwujudan dari perilaku tersebut didorong oleh adanya tiga factor utama yang mendukung, yaitu (1) kemauan; (2) kemampuan; dan (3) kesempatan bagi masyarakat untuk berpartisipasi, Dorodjatin (Slamet, 2003:18).

\section{PENUTUP}

\section{Kesimpulan}

Berdasarkan uraian pembahasan di atas maka dapat disimpulkan bahwa:

1. Partisipasi pemuda dalam pembangunan pengerasan jalan usaha tani, kegiatan pembangunan masjid, dan kegiatan pemugaran masjid di Desa Kasimpa Jaya Kecamatan Tiworo Selatan Kabupaten Muna Barat baik bentuk pikiran, tenaga ataupun uang/material dapat di lihat pada tahap pelaksanaan kegiatan pembangunan tersebut. Pada tahap pelaksanaan partisipasi pemuda cukup baik. Akan tetapi partisipasi pemuda dalam kegiatan pembangunan baik bentu $\mathrm{k}$ pikiran, tenaga ataupun uang/material pada tahap perencanaan dan evaluasi masih minim atau masih kurang.

2. Faktor-faktor yang mempengaruhi partisipasi pemuda dalam pembangunan desa di Desa Kasimpa Jaya Kecamatan Tiworo Selatan Kabupaten Muna Barat yaitu factor kemauan, kemampuan dan kesempatan. Dengan demikian faktor yang dominan yang mempengaruhi partisipasi pemuda adalah faktor kesempatan.

\section{DAFTAR PUSTAKA}

Mulyana, Deddy. 2011. Ilmu Komunikasi Suatu Pengantar, Bandung: PT. Remaja Rosdakarya.

Barry, Render, Dkk. 2006. Operation Management. Jakarta: Salemba Empat.

Irfani, Rahmat. 2004. Penyesuaian Diri Santri Di Pondok Pesantren Terhadap Kegiatan Pesantren Studi Kasus di Pondok Pesantren Darunnajah. Skripsi. Jakarta: Fakultas Psikologi Universitas Islam Negeri Syarif Hidayatullah

Kartono, Kartini. 1992.Pathologi Sosial 2 (Kenakalan Remaja). Jakarta: Raja Grafindo Persada.

Mubyarto, 2001. Prospek Otonomi Daerah dan Perekonomian Indonesia Pasca Krisis Ekonomi, Yogyakarta: BPFE2. 
Ndraha, Talizidun. 1990. Pembangunan Masyarakat. Jakarta: PT. Rineka Cipta.

Pardiman, S. 1981.Peranan Generasi Muda Dalam Pembangunan Nasional. Jakarta: Pustaka Jaya.

Raharjo, 1999. Pengantar Sosiologi Pedesaan Dan Pertanian. FakultasIlmu Social Dan Ilmu Politik.Gadja Mada

Siti, Irene, Astuti, Dwiningrum. 2011. Desentralisasi dan Partisipasi Masyarakat dalam Pendidikan. Yogyakarta: Pustaka Pelajar.

Sudibyo, Lies, Dkk. 2013. Ilmu Sosial Budaya Dasar. Yogyakarta : Andi Offset

Slamet. 2003. Pembangunan Masyarakat Berwawasan Partisipasi, Surakarta: Sebelas Maret University Press.

Slamet. 2006. Kesehatan Lingkungan. Yogyakarta: Gadjah Mada University Press. Sumaryadi, I Nyoman. 2010. SosiologiPemerintahan. Bogor: Ghalia Indonesia. 